\title{
New Additions to Turkish Gasteroid Fungi
}

\author{
Hasan Hüseyin DOĞAN ${ }^{1}$, Ilgaz AKATA ${ }^{2}$ \\ ${ }^{1}$ Selcuk University, Faculty of Science, Department of Biology, TR 42031 Konya, Turkey \\ ${ }^{2}$ Ankara University, Faculty of Science, Department of Biology, 06100, Tandoğan, Ankara Turkey \\ Sorumlu Yazar: e-mail: akata@ science.ankara.edu.tr
}

Geliş Tarihi: 06.08.2015

\begin{abstract}
Three gasteroid fungi species "Gautieria morchelliformis Vittad., Hysterangium stoloniferum Tul. \& C. Tul. and Gymnomyces mistiformis (Mattir.) T. Lebel \& Trappe" were reported for the first time from Turkey. Short descriptions, ecology, distribution and photographs of fruitbodies and micrographs of spores were given in the text.

Keywords: Gasteroid fungi, new records, mycobiota, Turkey
\end{abstract}

\section{Türkiye'nin Gasteroid Funguslarına Yeni İlaveler}

\section{Özet}

Üç gasteroid fungus türü . "Gautieria morchelliformis Vittad., Hysterangium stoloniferum Tul. \& C. Tul. and Gymnomyces mistiformis (Mattir.) T. Lebel \& Trappe" Türkiye'den ilk defa rapor edilmiştir. Türlerin kısa deskripsiyonu, ekolojisi, yayılışı, fruktifikasyon organlarının fotoğrafları ve sporların mikrografları metin içerisinde verilmiştir.

Anahtar Kelimeler: Gasteroid funguslar, yeni kayıtlar, mikobiyota, Türkiye

\section{Introduction}

The gasteroid fungi are polyphyletic group of fungi which belong to division Basidiomycota. Macro and micro morphological features as well as the development, maturation and dispersal of spores are characteristic properties of this group. Although they represent a small part of the total number of the divison members, gasteroid fungi contain a large range of morphological diversity. Unlike most Basidiomycota members, gasteroid fungi are angiocarps. The group contains both hypogeous and epigeous members. Fruit bodies of gasteroid fungi are partially or completely embedded in soil, at least during immaturity. As they mature they arise above the ground and becoming globose, pyriform or clavate. Most gastoid fungi are saprobe that grow on soil, dead wood or dung but some form mycorrhizal symbioses with plants (Calonge, 1998; Wilson et al., 2011; Łuszczyński and Tomaszewska, 2014).

Turkey is located between south-eastern Europe and Asia where is meeting ground of Euro-Siberian, Mediterranean, and IranoTuranian phytogeographical regions. Because of its location, climate, soil variability and plant diversity, the country is very suitable for the gasteroid fungal growth.
According to present literarure (Sesli and Denchev, 2008; Akata and Doğan, 2011; Türkoğlu and Castellano, 2013; Akata, 2014; Türkoğlu et al., 2015; Uzun et al., 2014), 108 gasteroid fungi species within the 15 families have previously recorded for Turkish mycobiota but Gautieria morchelliformis Vittad., Hysterangium stoloniferum Tul. \& C. Tul. and Gymnomyces mistiformis (Mattir.) T. Lebel $\&$ Trappe. have not yet been reported from Turkey.

The study aims to make contributions to Turkish gasteroid fungi

\section{Materials and methods}

The samples were collected from Konya province (Turkey) in 2014. Necessary morphological and ecological characteristics of the samples were recorded and they were photographed in their natural habitats. Then the samples were taken to the fungarium for further investigations. Microstructural data was obtained by using light microscope, and micrometers. Light microphotographs of basidiospores were taken by Leica DM 3000. Some reagents such as distillate water, $5 \% \mathrm{KOH}$, congo red etc. were used for identification The identification of the species was carried out 
using the literature (Montecchi and Sarasini, 2000; Gori, 2005). The identified samples were deposited at the Fungarium of Mushroom Application and Research Centre of Selçuk University.

\section{Results}

Short descriptions, ecology and distributions, photographs of fruit bodies and microphotographs of basidiospores of the species were provided. The systematics of the taxa were in accordance with Kirk et al. (2008).

Basidiomycota

Gomphales

Gomphaceae

Gautieria morchelliformis Vittad.

Macroscopic and microscopic features: Fruitbodies with Morchella apperance up to $8-10 \mathrm{~cm}$ across, subglobose-irregularly lobed, tuberiform, knotty, or even reniform shaped, tenacious, with a tuft of more or less numerous and consistent mycelial cords, sometimes like a rhizomorph (Figure 1a). Peridium whitish, thin, very soon fugacious. Gleba with variable dimensions well evident cells, sometimes disposed almost radially, labyrinthiform or subglobose or compressed shaped, up to 3-5 $\mathrm{mm}$ across, empty at maturity with walls covered with an ochrecinnamon spore powder, in contrast to the pinkish-brown walls; separated by gelatinized translucid tramal walls, with their small branches gradually linked to the main branches of a dendroid columella, becoming more and more thick while converging towards the bottom, where it often forms bigger nodes, and at the same time becoming whitish and cottony. Hymenium regular, basidia almost fusiform, same size as spores which vary in number, 1 to 4 . Smell very intense and pleasant at first, but finally heavy nauseating. Spores (7-)10.5-12.7 × 15.5$20.5(-24) \mu \mathrm{m}$, yellowish, ellipsoid, with an evident apiculus and generally flattened at the top, ornamented with 8-10 longitudinal or slightly inclined ribs, regular and smooth on their back, darker coloured (Figure 1d).

Habitat; This species is rare in Abies cilicica subsp. isaurica forest in soil at the $3-6 \mathrm{~cm}$ depth or it can be seen on soil when mature. It grows from June to July on the mountain elevations.

Specimen examined: TURKEYKonya-Hadim, Dedemli village, Türbe district, 1400m, 25.06.2014, HD 13344.

Hysterangiales

Hysterangiaceae

Hysterangium stoloniferum Tul. \& C. Tul.

Macroscopic and microscopic features:

Fruitbodies; $1-3 \mathrm{~cm}$ diam., subglobose, surface smooth, opaque, dry, whitish with leather-yellow spots, with a long, single mycelial cord, or surrounded by other slenderer, branched in the soil with many long sprouts and connected with other fruitbodies (Figure 1b).

Peridium; membranous, cartilaginous, separable when mature, thin 0.3-0.5 (1) mm thick when fresh.

Gleba; cartilagineous, tenacious and elastic, olive coloured to dirty greybrown; structure with very small, labyrinthiform-elongate cells, separated by translucent tramal plates, radially arranged and converging to the base, in correspondence with the beginning of the mycelial cord; basidia cylindrical, generally 4-spored.

Spores; 6.7-8.2 × 16.5-20 , smooth, hyaline or light greenish, ellipsoidfusiform, with a sterigmal appendix 1-2 $\mu \mathrm{m}$ long (Figure 1e).

Habitat; Samples were collected in oak (Quercus robur and Q. cerris) forest.

Specimen examined: TURKEYKonya-Hadim, Dedemli Village, Türbe district, 1400m, 25.06.2014, HD 13346.

Russulales

Russulaceae

Gymnomyces mistiformis (Mattir.) T.

Lebel \& Trappe

\section{Macroscopic and microscopic features:}

Fruitbodies; 1-2 cm diam., subglobose, surface pubescent when young and at the base slightly hollow, ivory-white at first, then reddish brown at maturity, with darker spots (Figure 1c).

Peridium; distinctly separable from the gleba, 1-2 mm thick, nearly lacking at the base in the cavity surfaces; structure made of filamentous hyphae, outside irregular and 
less broad, reddish brown, but more regular and subhyaline inside, near the gleba.

Gleba; snow-white when young, later ochre-brown to reddish, structure of very small cells, visible only under the lens, slightly radially arranged, convergent towards the base, where they become smaller and elongate. basidia clavate, $35-40 \times 13-15$ $\mu \mathrm{m}$, mostly 4-spored. Odour faint when fresh, similar to that of Tuber melanosporum when ripe.

Spores; 8.5-10.5 × 9.7-12.5 $\mu \mathrm{m}$, with a darker ornamentation of cylindrical aculei with a more or less rounded tip, up to 1-2 $\mu \mathrm{m}$ tall, distinctly amyloid, globose or broadly ellipsoid (Figure 1f).

Habitat; Samples were collected in mixed oak (Q.robur and Q. Ilex) forest.

Specimen examined: TURKEYKonya-Hadim, Dedemli Village, Türbe district, 1400m, 25.06.2014, HD 13345.

\section{Discussion}

Gautieria morchelliformis might be confused with G. trabutii (Chatin) Pat in terms of morphology and ecology but the former species could be distinguished by its alveolar structure at the gleba and Morchella like appearance while latter species is tuber like appearance and little small fruitbodies. In addition to spores of G. morchelliiormis are ornamented with 810 longitudinal or slightly inclined ribs, regular and smooth on their back, spores of G. trabutii are ornamented with several verrucose or hemispherical tubercles, up to 2-3 $\mu \mathrm{m}$ diam.

Hysterangium stoloniferum is characterized by a long mycelial cord without any other mycelial remnants attached to the fruitbodies surface. It differs from other genus members by its bigger spores.

Gymnomyces mistiformis can be easily separated from other members of the genus Gymnomyces by its distinctly amyloid and verrucose spores, and reddish brown peridium.

With the present study, Gautieria morchelliformis, Hysterangium stoloniferum and Gymnomyces mistiformis were recorded for the first time from Turkey and the Turkish gasteroid species number increased to

111.

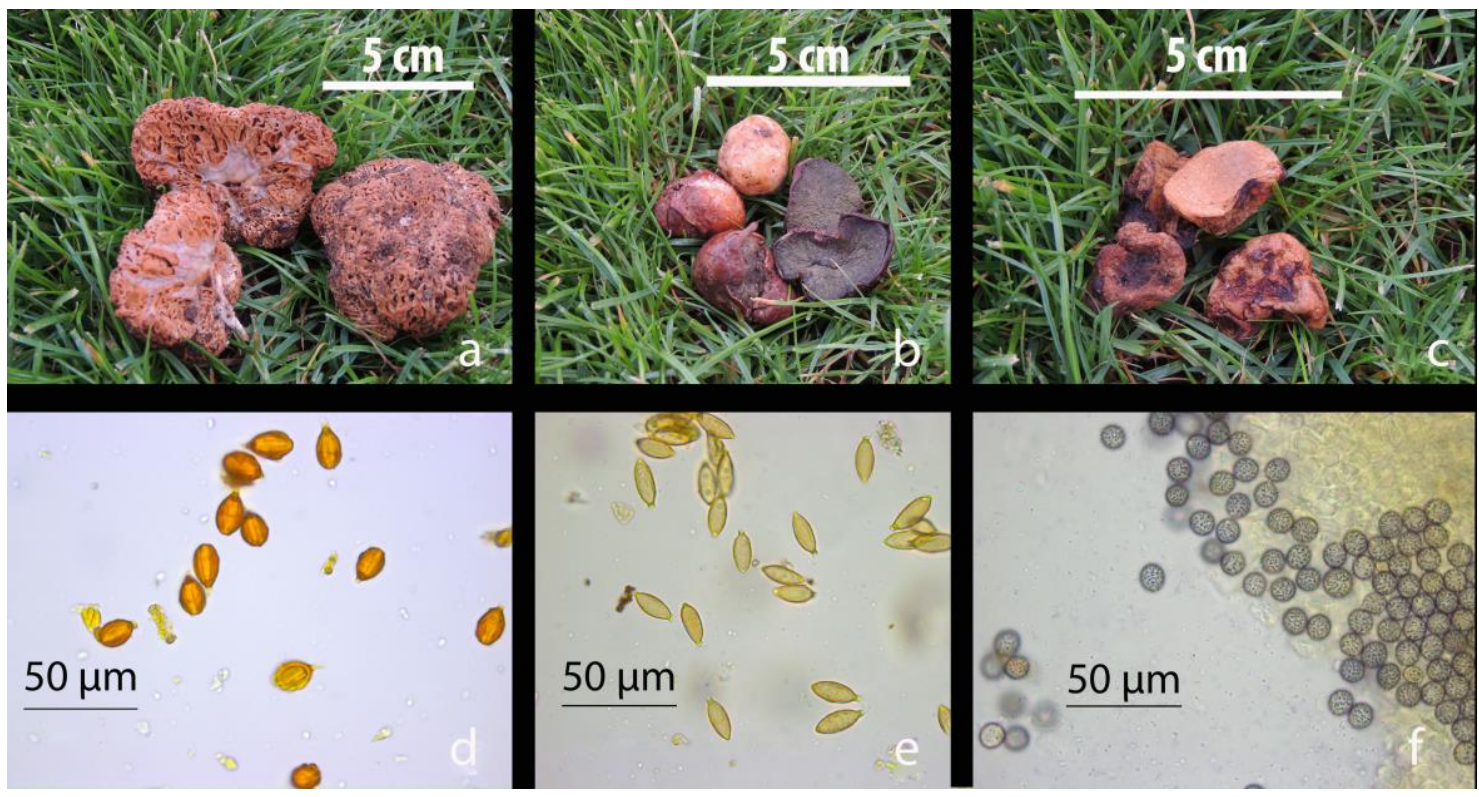

Figure1. Fruit bodies: a. Gautieria morchelliformis, b. Hysterangium stoloniferum, c. Gymnomyces mistiformis, Spores: d. Gautieria morchelliformis, e. Hysterangium stoloniferum, f. Gymnomyces mistiformis. 


\section{Acknowledgements}

The authors are indebted to the Foundation

TUBITAK (TBAG/113Z467) and the

Scientific Research Projects (BAP) Coordinating Office (BAP/14701228) at Selcuk University for their financial support of the current work. using the literature (Montecchi and Sarasini, 2000; Gori, 2005).

\section{References}

Akata I., Kaya A., Uzun Y. 2014 Macromycetes determined in Yomra (Trabzon) district. Turkish Journal of Botany, 38: 999-1012.

Akata I, Doğan HH. 2011. Pseudocolus fusiformis, an uncommon stinkhorn new to Turkish mycobiota. Mycotaxon, 115:259-262.

Calonge F.D. 1998. Gasteromycetes, I. Lycoperdales, Nidulariales, Phallales, Sclerodermatales, Tulostomatales. Volume 3., Real Jardin Botanico.

Gori L. 2005. Funghi Ipogei Della Della Lucchesia, 29 Marlia-Lucca: Lamberto Gori-Via Carlo Del Prete.

Kirk P.F., Cannon, P.F., Minter D.W., Stalpers J.A. 2008. Dictionary of the fungi, 10th ed. CAB International. Wallingford, UK.

Montecchi A., Sarasini M. 2000. Funghi Ipogei D'Europa, Vicenza: Fondazione Centro Studi Micologici dell'AMB.

Łuszczyński J, Tomaszewska A. 2014. Gasteroid fungi - the morphological characteristics of selected endangered and rare species noted in Poland. Folia Biologica et Oecologica, 10: 130-138.

Sesli E., Denchev, C.M. 2008. Checklists of the myxomycetes, larger ascomycetes, and larger basidiomycetes in Turkey. - Mycotaxon 106: 6567. + [complete version, 1-36, new version uploaded in February 2014].

Türkoğlu A., Castellano M. A. 2013. New records of truffle fungi (Basidiomycetes) from Turkey. Turk J Bot 37: 970-976.

Türkoğlu A, Castellano M A, Trappe J M, Yaratanakul Güngör M 2015. Turkish Truffles 1: 18 New Records for Turkey, Turk J Bot 39: 359376.

Uzun Y, Acar İ, Akata I. 2014. Notes on Turkish Melanogaster. Ot Sistematik Botanik Dergisi, 21 (2): 113-118.

Wilson A.W, Binder M, Hibbett D.S. 2011. Effects of gasteroid fruiting body morphology on diversification rates in three independent clades of fungi estimated using binary state speciation and extinction analysis. Evolution, 65(5): 13051322. 